\title{
Social Media Strategies on Brand Awareness at a Small Business Consultancy Firm in South Africa
}

\author{
https://doi.org/10.3991/ijim.v14i20.14831 \\ Tarisai Fritz Rukuni, Eugine Tafadzwa Maziriri $\left({ }^{\square}\right)$ \\ University of the Free State, Bloemfontein, South Africa \\ maziririeteufs.ac.za \\ Tsepo Mofoka \\ Ekurhuleni East TVET College, Johannesburg, South Africa
}

\begin{abstract}
Small and medium-sized enterprises - including those in the business consulting sector - are strategic for the growth of the South African economy and for the growth of marginalised economies by creating jobs and generating profits. However, the survival of SMEs is challenged by competitive pressure from international consulting firms such as PricewaterhouseCoopers, McKinsey and KPMG [8]. Small and medium-sized business consulting firms must adopt innovative survival strategies. Effective use of social media strategies is one strategy that SMEs should follow to influence brand awareness and brand loyalty and create a competitive advantage. An inability to use social media as a business strategy results in poor brand awareness, reduced sales and a closure of business. It is against this background that this study aimed to assess customers' perceptions of social media strategies employed by the small and medium business consultancy firm, investigate the relationship between social media strategies and brand awareness, and evaluate the relationship between brand awareness. A quantitative descriptive research methodology, using a structured questionnaire was employed to collect data from a sample of 231 customers at the business consultancy. The Statistical Package for Social Sciences version 25 was employed to conduct descriptive and multivariate analysis, including mean, standard deviation, correlation and regression analysis. Overall, the findings show that social media strategies had a statistically significant positive relationship with brand awareness. The research findings hold major implications for theory and practice.
\end{abstract}

Keywords-Social media, brand awareness, business consultancy competition

\section{Introduction}

South Africa requires input from small and medium-sized enterprises (SMEs) to rejuvenate the country's economy, which is facing a 29.1 per cent unemployment rate [7]. SME prosperity is important because it influences economic growth, job creation and income generation [16]. Moodliar [21] notes that SMEs participate in various sectors including the business consultancy industry. It is unfortunate that most SME 
consultancy firms in South Africa are collapsing in the face of competition from established consultancy firms like PricewaterhouseCoopers (PwC) and KPMG [8]. As information and communication technology (ICT) is gradually becoming a bigger and more relevant part of the daily life of individuals [49], it is recommended that social media tactics be used effectively as one of the methods for creating brand recognition and brand loyalty and staying competitive on the marketplace [23]. Failure to develop social media strategies leads to poor brand awareness and loyalty, which ultimately leads to undernourished market share, lower income levels and eventual business closure [16]. Authorities, like Barreda, Bilgihan, Nusair and Okumus [3] and Siddique and Rashidi [28] lament the fact that most SME consulting firms have not yet realized how important it is to handle social media strategies effectively. Barreda et al. [3] explain that failure to implement social media campaigns leads to a loss of brand recognition and loyalty. According to Rukuni et al. [24] and Zernigah and Sohail [36], the analysis of consumer attitudes towards social media approaches used to create brand recognition and loyalty is an effective strategy for social media management.

Against this background, it can be noted that there are some gaps in the existing empirical literature relating to an understanding of how social media strategies would influence building brand awareness; hence, there is a need for further scholarly introspection. Most international studies have been conducted in countries such as the United Kingdom (UK), Spain, Ireland, France, the United States of America and the Netherlands. For instance, Eid, Abdelmoety and Agag [9] examined the antecedents and consequences of social media marketing use among UK exporting business-tobusiness (B2B) SMEs. In addition, Stojanovic, Andreu and Curras-Perez [31] determined the effects of the intensity of the use of social media on destination brand equity among tourists who had visited the city of Valencia in Spain. Additionally, Jones, Packham, Beckinsale, Durkin, McGowan and McKeown [15] conducted a study, which explored social media adoption in SMEs in Ireland. Furthermore, Cawsey and Rowley [5] conducted a study, which focused on social media brand-building strategies amongst marketing professionals involved in managing social media programmes in B2B companies from France, Ireland, the United Kingdom and the United States. Moreover, Van Puijenbroek, Poell, Kroon and Timmerman [32] studied the relationship between social media use and learning activities undertaken by employees of three multinationals firms based in the Netherlands.

Within the South African context, previous scholars have conducted their studies in various contexts, by focusing on -the adoption of social media marketing by South African banks [6]; the effectiveness of using social networking technology for marketing in South Africa [17]; the adoption of social media and social media marketing by dentists in South Africa [29]; he use of social media and social networks as the promotional tool for rural small, medium and micro enterprises in KwaZulu-Natal [19]; and the influence of social media service quality on client loyalty in the South African banking industry [11].

Based on the above-mentioned South African studies conducted in different contexts, the relationship between social media strategies and brand awareness in South Africa has not been explicitly discussed. Therefore, it would be naïve and unwise to conclude a priori that results from the developed world can be applied without ques- 
tioning in developing nations, such as South Africa. Therefore, this lacuna is subject to clarification and often requires addressing itself.

The rest of the article progresses as follows: firstly, the problem statement is presented, and followed by the significance of the study. This is followed by a report on the review of literature and the development of the conceptual model as well as the hypotheses statements. The methodology that guides the study is then discussed. Finally, the results of the study, the discussion, implications and suggestions for future research are provided.

\section{The Problem Statement, Research Objectives and the Study Question}

SME consultancy firms in South Africa are experiencing extreme competition from global consultancy firms (i.e. PwC, KPMG, McKinsey and company) [8]. Keskin et al. [16] contend that the sustainability of these SME consultancies is strategic for South African economy growth. South African SME consultancy output leads to job growth, a rise in income and an alleviation of poverty. Owino et al. [23] recommend that customer assessments on the proper use of social media strategies be one of the methods that SME consultancies can use to build brand awareness and hedge against competition from global consultancy firms. This current study also plays a major role in uncovering the connection between social media strategies, brand awareness and brand acceptance within South Africa 's SME consultancy companies. In this study the research objectives were as follows:

- To assess customers' perceptions of social media strategies used by a business consultancy firm

- To investigate how a social media strategy would influence brand awareness

The research question was formulated in terms of the extent to which social media strategies influence brand awareness of a business consultancy firm in the City of Tshwane.

\subsection{Significance of the study}

In line with social media, brand awareness and brand acceptance, the present study is of great significance for the management of the SME consulting firm and the theory extension. Carrying out this analysis aided the SME consulting company in formulating social media approaches with a customer-centric approach. Consequently, this study gave the SME consultancy firm an opportunity to understand the perceptions of its customers regarding their use of social media to build brand awareness. The findings from this study can be used as a reference point from which activities can be updated in line with social media use. Social networking became a recent and growing tool by which customers are reached. It is important for the SME company to follow a customer-cantered approach to advice the appropriate use of the channel to gain brand awareness, create brand popularity, increase sales and eventually growth. This study 
connected theory of social media with brand management in the context of SME consulting firms, a field that has remained unexplored in literature until now. Conducting this research offered an opportunity to check the relationship between social media views of the consumers and brand awareness. A description of the literature review that provided the basis for this analysis is presented in the next section.

\section{The Literature Review}

Pamacheche, Chinomona and Chuchu [38] argue that literature serves the function of sharing results from other studies relevant to the research at hand, linking the research to a broader ongoing literature conversation as well as filling gaps and expanding previous studies. Therefore, the literature was reviewed around the variables of this research after a search on academic online databases and search engines. This section of the literature review discusses the various variables of research being studied as part of this study.

\subsection{Social media}

The most recent interactive form of social interaction comprises social media [1]. Shishikala and Mahapatro [27] define social media as a platform used by a business to generate content that is intended to encourage consumers to share messages with family and friends, thus creating brand awareness and advocacy. Social media operates across such sites as Twitter, Facebook, WhatsApp and Instagram [2]. Additionally, Papadakis, Zaranis, and Kalogiannakis [37] explained that interacting with digital / social media technologies provides creative freedom for individuals to explore useful content. Appropriate strategies must be used to realize the effective use of the social media. Rukuni et al. [24] and Zernigah and Sohail[36] point out that social media strategies are informative, entertaining, avoiding irritation and creditable as sources. Appropriate utilization of social media strategies creates a competitive advantage. Social media effectiveness is based on the strategies the user adopts in promoting brand awareness and loyalty [22];[25]. The current study argued that adopting a customer-centric approach is compulsory from a customer perspective to inform social media strategies. In the subsections below, social media strategies are further expounded.

\subsection{Informativeness}

Informativeness refers to the level of usefulness to its customers of information carried by social media platforms [4]. Zernigah and Sohail[36] as well as Saadeghvaziri and Hosseini[25] allude to the point where social media platforms, such as WhatsApp, Twitter, Facebook and Instagram, are useful, depending on the level of information they carry. Organisations will exchange knowledge about the functionality of their goods and services with social media employees [13]. Pricing and promotional messages can include information that can be exchanged via social media. 
Hutter, Hautz, Dennhardt and Fuller [14] explain that social media is therefore an excellent platform through which an organization can disseminate important information to its market, particularly when it can tailor the content to the requirements of customers. Kioko [18] also found that the more informative the social media platforms are, the greater their impact on building awareness and loyalty to the brand. Consequently, the current study sought to understand the perceptions of customers about information and its influence on brand awareness in an environment involving a SME consultancy firm.

\subsection{Entertainment}

'Entertain' is defined as the act of pleasing a customer's use of words, images, and videos through a social media platform [28]. According to Vries and Carlson [33], businesses use entertainment to tip social media posts to their consumers ' needs. Therefore, entertainment has become an important strategy used in social media strategies. Shashikala and Mahapatro [27] accept that social media posts will bear some amusing qualities for the intended target audience to achieve readability. In addition, Dehghani, Niaki, Ramezani and Sali [47] have decided that providing a higher entertainment value is likely to give media consumers a profit that encourages them to use the media more often. So, entertainment is an important tool that businesses can use to ensure the impact of social media. However, consumers should be assessing the sufficiency of the entertainment interest of a social media post.

\subsection{Irritation avoidance}

'Irritation' refers to the level of annoyance arising from reading content on social media [24]. Zernigah and Sohail [36] state that messages on social media need to be free of irritating aspects. It's easy to pass non-irritating social media messages from one customer to another [34]. A firm's ability to track social media irritability is a popular strategy that strategic organisations should adopt [13]. Non-irritating messages are often crucial to creating recognition and loyalty for the brand. It was relevant for the SME consultancy firm under study to understand their customers' attitudes regarding the degree of frustration reflected in the message of social media.

\subsection{Source credibility}

The information source's credibility is a key component which customers consider when receiving social media messages [35]. According to Ghane, Shokrizadeh, Omidvar, and Comyab [12], different factors affect the credibility of social media posts, such as the company's reputation for sending the message and the number of years of existence. It's also important to note that the higher the message's credibility, the greater its impact on building brand awareness and loyalty [4]. Hence, the researchers tried to grasp consumer expectations of the SME consultancy firm's credibility. 


\subsection{Brand awareness}

Brands can effectively improve their robust customer relationships [46]. Brand awareness is recognizability, information, and product ideas [40]. Ekhveh and Darvishi[41] and Kalogiannakis and Papadakis [50] point out that brand awareness is linked to the information node in memory; their brand awareness is defined by the ability of consumers to recognise a brand under a variety of conditions. Jamil and Wong [42] defines brand awareness as a brand identity and a brand recall. Brand awareness generates a great connection between memory and a particular brand [43]. Brand awareness is one of the key factors in creating brand added value and is also seen as one of the key factors influencing customer perception. Today, social media not only reinforce current consumer-to-customer and firm-to-customer relationships, but also bring a transition to traditional alternatives, improving firms' ability to engage with consumer dialog and thereby increasing their contact tool [47]. Social media will create and increase brand awareness [48] because a large number of people are already using social media, a brand name distributed across those networks will help inform people about it and distributed across the business, increasing brand awareness.

\section{The Conceptual Theoretical Model}

The conceptual theoretical model displayed in Figure 1 is grounded on the viral marketing conceptual model developed by Rukuni et al. [24]. Based on this conceptual model, it is conceptualised that there is a statistically significant relationship between social media strategies and brand awareness. In this study, social media strategies represent independent constructs, comprising informativeness, entertainment, irritation avoidance and source creditability. On the other hand, brand awareness is the dependent construct.

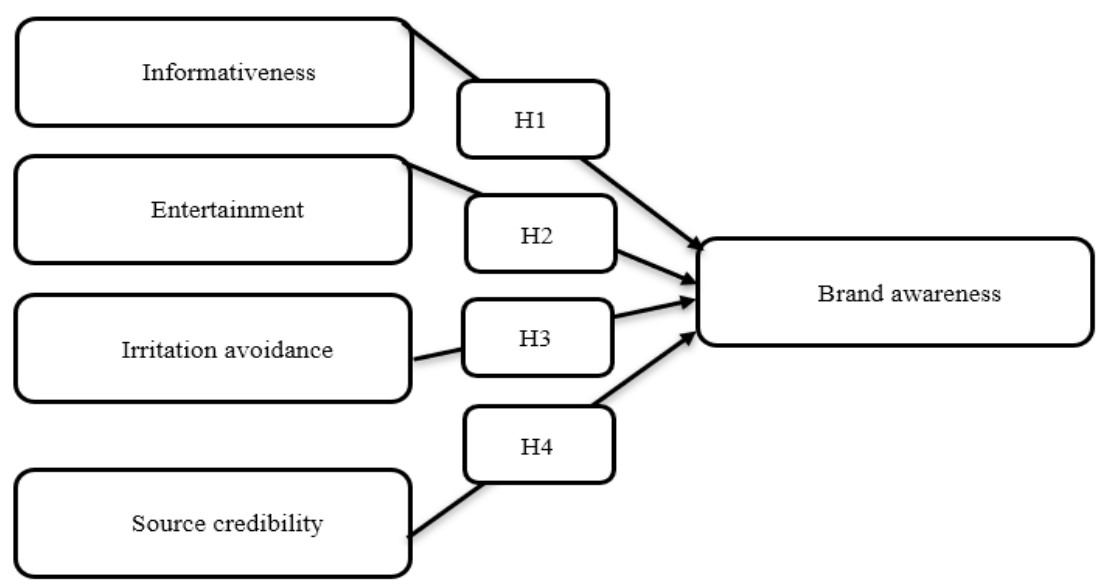

Fig. 1. Conceptual theoretical model (Adapted from: Rukuni et al. [24]) 
Note:

- H1: There is a statistically significant relationship between social media informativeness and brand awareness.

- H2: There is a statistically significant relationship between social media entertainment and brand awareness.

- H3: There is a statistically significant relationship between social media irritation avoidance and brand awareness.

- H4: There is a statistically significant relationship between social media source credibility and brand awareness.

\section{$5 \quad$ Research Methodology and Design}

The researcher's ontological assumption in an objective manner was that social media informativeness, social media entertainment, social media irritation avoidance and social media source credibility are all instrumental in determining brand awareness. Therefore, from the ontological perspective of objectivism of the research, this investigation adopted a positivist paradigm and deductive reasoning, as it seeks to discover a link between the variables presented for this analysis as well as the use of measurement instruments for gathering data. Hence, a quantitative approach was applied as it improves accuracy of findings by means of statistical analysis. The design was suitable to solicit the required information relating to social media informativeness, social media entertainment, social media irritation avoidance, social media source credibility, brand awareness and acceptance. Data collection was carried out using a self-completion questionnaire adapted from Rukuni et al. [24], which was adjusted to suit this study. A pilot study was carried out with 10 customers to ensure that the measurement tool was free from grammatical and spelling mistakes. The business consultancy firm had a total population of 250 customers in its database, and an online SurveyMonkey® questionnaire link was sent to every unit of the total population by the business consultancy to allow conveniently available customers to participate in the study. A convenience sample of 231 customers responded with completed questionnaires. The Statistical Package for Social Sciences (SPSS) version 25 was used to conduct descriptive and inferential data analysis to obtain the mean, standard deviation, correlation and regression analysis. In line with the recommendations made by Saunders, Lewis and Thornhill [26], tests for reliability and validity were carried out using Cronbach's alpha and factor analysis respectively. The next section presents the findings of the study.

\section{$6 \quad$ Results and Discussion}

This section provides the results on customers' perceptions of social media strategies, namely informativeness, entertainment, irritation avoidance and source credibility. A five-point Likert-type scale (strongly agree $=1$; strongly disagree $=5$ ) was used to measure perceptions of customers on each of the strategies. Customer perceptions 
of each construct were calculated as a summated average of items under each construct. In this study, a mean value $(0.1-2.0)$ indicated positive perceptions while (2.2-5.0) indicated negative perceptions on the social media strategy used by the business consultancy firm. Table 1 provides results on perceptions of customers on social media strategies.

Table 1. Perceived social media strategies - descriptive statistics $(n=231)$.

\begin{tabular}{|c|c|c|c|}
\hline & Constructs and items & Mean & SD \\
\hline & Informativeness & 2.55 & 1.05 \\
\hline SMI1 & I find Facebook messages of the consultancy firm informative. & 2.36 & 1.04 \\
\hline SMI2 & Marketing messages displayed on twitter for the consultancy firm are informative. & 2.56 & 1.03 \\
\hline SMI3 & $\begin{array}{l}\text { Instagram pages on social networking sites for the consultancy firm are informa- } \\
\text { tive. }\end{array}$ & 2.52 & 1.07 \\
\hline SMI4 & $\begin{array}{l}\text { Facebook advertisements by the consultancy firm provide useful information } \\
\text { about services. }\end{array}$ & 2.51 & 1.07 \\
\hline \multirow[t]{2}{*}{ SMI5 } & Facebook content of the consultancy firm are receiving many likes. & 2.81 & 1.08 \\
\hline & Entertainment & 2.85 & 1.10 \\
\hline SME1 & $\begin{array}{l}\text { I find marketing messages received from the consultancy firm via Twitter enter- } \\
\text { taining. }\end{array}$ & 2.79 & 1.10 \\
\hline SME2 & $\begin{array}{l}\text { Facebook messages of the consultancy firm on social networking sites is enter- } \\
\text { taining. }\end{array}$ & 2.82 & 1.18 \\
\hline SME3 & $\begin{array}{l}\text { The element of humour of the Facebook messages of the consultancy firm is } \\
\text { entertaining. }\end{array}$ & 2.86 & 1.11 \\
\hline \multirow[t]{2}{*}{ SME4 } & I share the consultancy firm's Twitter entertaining views about their services. & 2.95 & 1.04 \\
\hline & Irritation avoidance & 2.92 & 1.07 \\
\hline SMIR1 & $\begin{array}{l}\text { Facebook marketing messages of the consultancy firm are not a source of irrita- } \\
\text { tion. }\end{array}$ & 2.80 & 1.06 \\
\hline SMIR2 & $\begin{array}{l}\text { I believe that Facebook messages from the consultancy firm do not contain virus- } \\
\text { es. }\end{array}$ & 2.86 & 1.07 \\
\hline SMIR3 & Marketing messages on Facebook of the consultancy firm are not irritating. & 2.99 & 1.08 \\
\hline SMIR4 & The consultancy firm's Twitter advertisements are not annoying. & 2.99 & 1.08 \\
\hline \multirow[t]{2}{*}{ SMIR5 } & I find Twitter of the consultancy firm not irritating. & 3.00 & 1.07 \\
\hline & Source credibility & 2.85 & 1.10 \\
\hline SMS1 & $\begin{array}{l}\text { I trust the information provided by marketers of the consultancy firm through } \\
\text { Facebook. }\end{array}$ & 2.79 & 1.10 \\
\hline SMS2 & Content on Twitter sites of the consultancy firm is reliable. & 2.82 & 1.18 \\
\hline SMS3 & Facebook advertisements received from the consultancy firm is not misleading. & 2.86 & 1.11 \\
\hline \multirow[t]{2}{*}{ SMS4 } & Twitter information provided by the consultancy firm is accurate. & 2.95 & 1.04 \\
\hline & Brand awareness & 2.68 & 0.98 \\
\hline BAW1 & Twitter strategies used by the consultancy firm leads to brand recognition. & 2.58 & 0.97 \\
\hline BAW2 & $\begin{array}{l}\text { The use of Facebook by the consultancy firm resulted in the perception of top } \\
\text { brand. }\end{array}$ & 2.53 & 0.97 \\
\hline BAW3 & $\begin{array}{l}\text { Twitter strategies used by the consultancy firm makes me remember the brand } \\
\text { better. }\end{array}$ & 2.65 & 0.99 \\
\hline BAW4 & $\begin{array}{l}\text { I consider the Facebook strategies of the consultancy firm as a useful marketing } \\
\text { tool for creating brand awareness. }\end{array}$ & 2.97 & 0.99 \\
\hline
\end{tabular}

Note: $\mathrm{SMI}=$ social media informativeness; SME = Social media entertainment; SMIR = social media irritation avoidance; $\mathrm{SMS}=$ social media source credibility; BAW $=$ social media brand awareness 
Results indicated that all social media strategies had mean values above 2.0 , which means customers had negative perceptions on all social media strategies used by the business consultancy firm. Irritation avoidance had the highest negative perception with a mean value of 2.92 . This was followed by entertainment with 2.85 , source creditability with 2.85 and informativeness with 2.55 . Moreover, customers had negative perceptions on brand awareness as indicated by the mean value at 2.68. In a study carried out at a supermarket in Johannesburg, Rukuni et al. [24] found that customers had negative perceptions on irritation avoidance, entertainment, source creditability and informativeness as strategies for viral marketing.

\subsection{Reliability and validity test}

Reliability and validity of the measurement instrument in this study were ensured through the use of Cronbach's alpha and factor analysis, respectively [10]. Saunders et al. [26] posit that Cronbach's alpha should reach a minimum threshold of 0.7 for a construct to be regarded as reliable. Field [10] argues that factor analysis should reach a minimum threshold of 0.4 for the validity of an item used in the measurement instrument to be declared. Table 2 reflects the results of the reliability and validity tests. The results of these tests are provided in Table 2.

Table 2. Results of validity and reliability analysis on items representing social media strategies $(\mathrm{n}=231)$

\begin{tabular}{|c|c|c|c|c|c|}
\hline & 1 & 2 & 3 & 4 & 5 \\
\hline SMI1 & .63 & & & & \\
\hline SMI2 & .68 & & & & \\
\hline SMI3 & .74 & & & & \\
\hline SMI4 & .67 & & & & \\
\hline SMI5 & .65 & & & & \\
\hline SME1 & & .73 & & & \\
\hline SME2 & & .83 & & & \\
\hline \begin{tabular}{|l|} 
SME3 \\
\end{tabular} & & .78 & & & \\
\hline SME4 & & .75 & & & \\
\hline SMIR1 & & & .67 & & \\
\hline SMIR2 & & & .70 & & \\
\hline SMIR3 & & & .67 & & \\
\hline SMIR4 & & & .62 & & \\
\hline SMIR5 & & & .66 & & \\
\hline SMS1 & & & & .73 & \\
\hline \begin{tabular}{|l|} 
SMS2 \\
\end{tabular} & & & & .83 & \\
\hline SMS3 & & & & .78 & \\
\hline SMS4 & & & & .75 & \\
\hline BAW1 & & & & & .83 \\
\hline BAW2 & & & & & .79 \\
\hline BAW3 & & & & & .80 \\
\hline BAW4 & & & & & .81 \\
\hline$\alpha$ & .88 & .88 & .95 & .88 & .87 \\
\hline
\end{tabular}

Note: $\mathrm{x} *<0.4$ where $\mathrm{x}=$ factor score 
In this study, 22 items representing social media strategies and brand awareness and acceptance. All items used in this study were valid and reliable. Consequently, it was decided to proceed with inferential analysis, as presented in the next section.

\subsection{Correlation analysis}

The Pearson correlation coefficient (r), which assesses the degree to which quantitative variables are linearly related in a sample, was used [44]. Correlation analysis tests the strength and direction of a relationship between two or more constructs [20]. Stangor [30] alludes to two parameters, namely include the Pearson coefficient ( $\mathrm{r}$ value) and the probability value (p-value), which are used to measure the relationship between constructs. Saunders et al. [26] state that the r-value ranges from -1 to 1 , where -1 indicates that there is a perfect negative relationship while 1 shows a perfect positive relationship. On the other end, the p-value indicates the statistical significance of the relationship [20]. In this study, a relationship between constructs was statistically significant when the p-value was equal to or less than 0.05 . Table 3 illustrates the results of the correlation analysis.

Table 3. Correlation analysis $(n=231)$

\begin{tabular}{|c|l|c|c|c|c|c|}
\hline & \multicolumn{1}{|c|}{ Variables } & $\mathbf{1}$ & $\mathbf{2}$ & $\mathbf{3}$ & $\mathbf{4}$ & $\mathbf{5}$ \\
\hline 1 & Informativeness & 1 & & & & \\
\hline 2 & Entertainment & $.66^{*}$ & 1 & & & \\
\hline 3 & Irritation avoidance & $.54^{*}$ & $.66^{*}$ & 1 & & \\
\hline 4 & Source credibility & $.66^{*}$ & $.86 *$ & $.66 *$ & 1 & \\
\hline 5 & Brand awareness & $.73 *$ & $.80 *$ & $.61 *$ & $.80 *$ & 1 \\
\hline
\end{tabular}

Note: $* \mathrm{p}<.001$

The results in Table 3 above show that there was a correlation between social media strategies and brand awareness. Consequently, a statistically significant moderate positive relationship was found existing between social media strategies and brand awareness. The next section provides the results of the regression analysis and hypotheses testing.

\subsection{Regression analysis and hypotheses testing}

Regression analysis was utilised to test the formulated hypotheses in the current study. In this study multiple linear regression analysis was performed to identify the variables that predicted or provided the best explanation for the portion of the total variance in the scores of the dependent variables [44]. The results are reported in Table 4. In this table, the strength of the relationship is indicated by the R-value, which takes the same value as beta $(\beta)$. The significance of the results is also shown by $\mathrm{p}$-value represented in this table as sig. As already stated, the statistical significance of the results is indicated by the p-value. The $\mathrm{R} 2$ is the explanatory value that shows the strength and impact of each social media strategy on brand awareness. 
Table 4. Regression Analysis (Dependent variable: Overall Brand awareness $(n=231))$

\begin{tabular}{|l|c|c|c|c|l|}
\hline Independent variables: Social media strategies & Beta & $\mathbf{T}$ & $\mathbf{S i g}$ & $\mathbf{R}^{\mathbf{2}}$ & Hypothesis \\
\hline Perceived informativeness & 0.730 & 16.310 & $0.000^{*}$ & 0.540 & Accept H1 \\
\hline Perceived entertainment & 0.800 & 20.340 & $0.000^{*}$ & 0.640 & Accept H2 \\
\hline Perceived irritation & 0.610 & 11.740 & $0.000^{*}$ & 0.610 & Accept H3 \\
\hline Perceived source credibility & 0.730 & 8.190 & $0.000^{*}$ & 0.540 & Accept H4 \\
\hline
\end{tabular}

Note: $* \mathrm{p}<0.001$

\section{$7 \quad$ Outcome of Hypotheses Testing}

\subsection{Testing of hypothesis 1}

Hypothesis 1, which stated that there is a statistically significant relationship between informativeness and brand awareness, could be accepted at the $\mathrm{p}<0.001$ statistically significant level. This decision was based on regression analysis results ( $\mathrm{r}$ value $=0.730 ; \mathrm{p}<0.001)$, which indicated that there was a statistically significant positive relationship between informativeness and brand awareness. This finding confirms the results by Muzaffar and Kamran [22] and Siddique and Rashidi [28] who also found that the use of strategies, such as informativeness in social media, results in brand awareness.

\subsection{Testing of hypothesis 2}

Hypothesis 2, which stated that there was a statistically significant relationship between entertainment and brand awareness could be accepted at the $\mathrm{p}<0.001$ significant level. This decision was made based on the regression analysis results ( $r$-value $=$ $0.800 ; \mathrm{p}<0.001)$ indicating that there was a positive relationship between entertainment and brand awareness. A research conducted by Shashikala and Mahapatro [27] and Saadeghvaziri and Hosseini [25] revealed that social media had an effect on customer behaviour, which is consistent with the current study findings. Arli [45] mentioned that the element of entertainment should become a main feature of its social media in the context of social media promotion. For example, creating daily games, hash-tag competitions and offering followers rewards [45].

\subsection{Testing of hypothesis 3}

Hypothesis 3, which stated that there was a statistically significant relationship between irritation avoidance and brand awareness was accepted at the $p<0.001$ significant level. The decision was made based on the regression analysis results ( $r$-value $=$ $0.610 ; \mathrm{p}<0.001)$, which indicated the existence of a relationship between irritation avoidance and brand awareness. The findings in the current study were consistent with the results of Zernigah and Sohail [36] as well as Muzaffar and Karan [22] who 
also found that there was a positive connection between non-irritating messages and brand awareness.

\subsection{Testing of hypothesis 4}

Hypothesis 4, which stated that there was a statistically significant relationship between source credibility and brand awareness was accepted at the $\mathrm{p}<0.001$ significant level. The decision was based on the regression analysis results ( $r$-value $=0.610$; $p<0.001$, which indicated the existence of a relationship between source credibility and brand awareness. This finding is consistent with the findings of Ghane et al. [12], who found there was a positive relationship between reputation as a source of social media and brand awareness.

\section{Conclusion on Research Objectives}

In a nutshell, this paper contributes to research by looking at factors that can contribute in establishing brand awareness in an organisational set up. Important contributions also emanated from examining the direct relationships in the social media usage literature by seeking to enhance a nuance understanding on the nexus between social media informativeness, social media entertainment, social media irritation avoidance, social media source credibility and brand awareness. Furthermore, regarding objective (i), which sought to assess customers' perceptions of social media strategies used by the business consultancy, it was concluded that customers had negative perceptions on social media strategies. The conclusion was based on the descriptive analysis results indicating that irritation avoidance had the highest negative perception with a mean value of 2.92 , followed by entertainment at 2.85 , source creditability at 2.85 and informativeness at 2.55. Regarding objective (ii), which sought to investigate the influence of social media strategies on brand awareness, it was concluded that informativeness, entertainment, irritation avoidance and source creditability had a statistically significant relationship with brand awareness. It was also concluded that social media strategies influence brand awareness and acceptance at varying levels. This was obtained from the explanatory power of each dimension. In this research, entertainment and source creditability with $\mathrm{R} 2=0.64$ were found to have a higher influence on brand awareness. This was followed by irritation avoidance with $\mathrm{R} 2=$ 0.61 and source creditability with $\mathrm{R} 2=0.54$ respectively. These results were also critical in providing an answer to the research question, namely "To what extent do social media strategies influence brand awareness and acceptance of the business consultancy firm in the City of Tshwane?" It was concluded that social media strategies influenced brand awareness and acceptance of the business consultancy firm to a greater extent and at varying levels. 


\section{Implications for Practice}

The results of this study - especially regarding the perceptions of customers about social media strategies and their uses - generated the need for the business consultancy to provide recommendations. The recommendations are consistent with the actions required to bring competitive advantage to the business consultancy. The sub-sections below provide the line of actions that should be pursued.

\subsection{Create useful information on social media platforms}

Social networking sites are not the question in most cases but rather the process by which they are employed leaves much to be desired. Information control must be in effect when using social media sites. The business consultancy should ensure that the messages sent via viral marketing contain informative content. Kalogiannakis, Vassilakis, Alafodimos, Papadakis, Papachristos and Zafeiri [51] and Kalogiannakis and Papadakis [52] also argue that keeping social media informative result in lifelong learning which relates to effective brand awareness. When paired with useful information, customers are drawn to a social forum.

\subsection{Use a flair of entertainment in the social media message}

Apart from insightful communications, it is made more desirable by arranging the entertainment in the post. Interesting advertisements captivate human beings. So, ensuring that entertaining content is included in the message is critical for the business consultancy. For the business consultancy to remain relevant when using interesting messages, therefore, innovation is required.

\subsection{Avoid the use of irritating messages}

Irritating message is a formula to generate frustration from the customers. The organization will make sure that the communications used do not irritate by seeking customer input. Through customer feedback, the general perceptions of customers on the messages used on social media platforms can be measured.

\subsection{Show authenticity in messages}

It is important to be truthful about the message sent via social media. Data usually submitted by the business consultant is linked to facilities and features on costs. The business will ensure that the information provided to customers is correct, so that no adjustments can arise as customers visit the consultancy. This is important for creating the necessary customer confidence. 


\subsection{Answer customer inquiries quickly}

There must be a policy specifying the procedures applied when addressing customer inquiries. Customer inquiries to keep customers engaged should be answered within 24 hours. Responding to customer inquiries indicates that the business consultancy is dedicated to its customers. Not reacting to consumer inquiries on social media generates the impression that the medium of contact is not essential to the ororganisation, resulting in the lack of focus.

\subsection{Build customer relationships through social media}

Social networking must be used as a tool to establish relationships with customers. So, maintaining active consumer engagement on social media is critical. Therefore, the use of active customer interaction is essential to establishing successful customer ties. When interacting with customers on social media, there must be personalised interaction.

\subsection{Stimulate conversation with customers}

Conversations with clients are critical to activate. Consumer interaction enhancement helps to get positive customer involvement. Therefore, it is important to conduct constant research on interesting topics that can be used to attract the attention of customers. This is an essential process by which a company can keep its clients active in the organisation.

\subsection{Create an active social media management team}

A team must be set up to properly monitor the social media activities. This team will interact regularly with the customers. The content of the social media sites should also be kept relevant and important.

\section{Recommendations}

The following recommendations are offered based on the analysis of the literature, and more specifically in the light of the findings of the empirical research.

- Taking into consideration that social media informativeness, social media entertainment, social media irritation avoidance and social media source credibility are all instrumental in determining brand awareness. It is recommended that brand managers be vigilant or ensure that they use these social media tactics to enhance brand awareness [50].

- It is imperative to note that social media platforms should be de-signed carefully to provide entertainment, avoid irritation and be a source of credibility. This view mirrors with the works of Zollo, Filieri, Rialti, and Yoon [39] who argue that social 
media marketers should invest in content, engagement, trend, optimization, and word-of - mouth interactions to meet cognitive, inclusive, and hedonic desires.

- To survive in a competitive environment, brand managers, particularly SMEs, should create and maintain strong brand-consumer relationships in social media environments in order to promote brand awareness. This initiative can be improved by incorporating an element of entertainment, usefulness and informativity, making communicating and interaction between the business and consumers. Applying the process of lifelong learning through social media is also of paramount importance in ensuring brand awareness [51].

\section{Limitations of the Study}

Despite the germane insights offered by this study, this study had limitations which are expected to lead to future research. The first limitation of this study is connected to the sample of the study, which comprised only customers engaged with the organisation through social media platforms, such as Twitter, Facebook and Instagram. A group of customers who were using WhatsApp only to communicate with the organisation was not considered. The second limitation concerned the time spent to collect data. Data collection took only three months to be completed since the study was cross-sectional. The change in customer perceptions that usually take place over a long period could not be accommodated in this study. Thirdly, this study used a strictly quantitative research methodology and a SurveyMonkey questionnaire to collect data. Respondents were therefore not allowed to respond in their own words, which is common in qualitative studies.

\section{Direction for Future Research}

Future research can be carried out including social media platforms that were not included in this study, for example, WhatsApp. It will be interesting to note the opinions of customers on the use of WhatsApp by the business consultancy. The use of a longitudinal research approach will be appreciated in future research. Using a longitudinal research approach will assist in capturing changes in perceptions of customers over time. Future research can make use of statistical data analysis methods such as structural equation modelling to get robust insight into the relationship between constructs. A qualitative research methodology can also be used in the place of quantitative techniques. The use of qualitative research techniques would allow the researcher to gain a better understanding of customers since responses to questions are provided in respondents' own words. 


\section{References}

[1] Arora, S \& Sharma A. (Social media: a successful tool for brand awareness. International Journal of Business and General Management, 2(3):1-14.

[2] Bampo M., Ewing M.T., Mather, D.R., Stewart D, \& Wallace M. (2008). The effects of the social structure of digital networks on social media performance. Information Systems Research, 19(3), 273-90. https://doi.org/10.1287/isre.1070.0152

[3] Barreda, A.A., Bilgihan, A, Nusair, K \& Okumus F. (2015). Generating brand awareness in online social networks. Computers in Human Behaviour, 50(10, 600-9. https://doi.org/ 10.1016/j.chb.2015.03.023

[4] Blanco, C.F., Blasco, M.G \& Azorin I.I. (2010). Entertainment and informativeness as precursory factors of successful mobile advertising messages. Communications of the IBIMA, 1(1), 1-11. https://doi.org/10.5171/2010.130147

[5] Cawsey, T., \& Rowley J. (2016). Social media brand building strategies in B2B companies. Marketing Intelligence \& Planning, 34(6), 754-76. https://doi.org/10.1108/ mip-04-2015-0079

[6] Chikandiwa, S.T., Contogiannis, E \& Jembere E. (2013). The adoption of social media marketing in South African banks. European Business Review, 25(4):365-81. https://doi.o rg/10.1108/ebr-02-2013-0013

[7] CNBC Africa. South Africa Q4 unemployment rate remains unchanged at 29.1\% [Online] 2020 [accessed 2020, February 11]; Available: https://www.cnbcafrica.com/news/financ $\underline{\text { ial/2020/02/11/south-africa-q4-unemployment-rate-remains-unchanged-at-29-1. }}$ https:// doi.org/10.1787/888933139328

[8] Consulting firms SA. (2017). List of consulting firms in South Africa [Online] 2017 [accessed 2017, April 5]; Available: http://www.consultingase101.com/list-of-consultingfirms-in-johannesburg-south-africa/

[9] Eid, R., Abdelmoety, Z \& Agag G. (2019). Antecedents and consequences of social media marketing use: an empirical study of the UK exporting B2B SMEs. Journal of Business \& Industrial Marketing, 35(2),284-305. https://doi.org/10.1108/jbim-04-2018-0121

[10] Field A. (2009). Discovering statistics using SPSS. 3rd ed. Thousand Oaks, CA: Sage.

[11] Gavaza, B.K., Viljoen, K.L \& Cilliers, L. (2019). The influence of social media service quality on client loyalty in the South African banking industry. Acta Commercii, 19(1):110. https://doi.org/10.4102/ac.v19i1.695

[12] Ghane N, Shokrizadeh H, Omidvar M, Comya H. Investigating the effective factors on electronic trade by viral marketing. Management Science Letters 4(4), 713-20. https://doi. org/10.5267/j.msl.2014.2.020

[13] Gunelius, S. (2011). 30 minutes social media marketing: step by step techniques to spread the words about your business. City, abbreviated state name: McGraw-Hill.

[14] Hutter, K., Hautz, J., Dennhardt, S \& Fuller J. (2013). The impact of user interactions in social media on brand awareness and purchase intention: the case of MINI on Facebook. Journal of Product \& Brand Management, 25(5/6), 342-51. https://doi.org/10.1108/jpbm05-2013-0299

[15] Jones, P., Packham, G., Beckinsal, M., Durkin, M., McGowan, P \& McKeown N. (2013). Exploring social media adoption in small to medium-sized enterprises in Ireland. Journal of Small Business and Enterprise Development, 20(4), 716-34. https://doi.org/10.1108/js bed-08-2012-0094

[16] Keskin, H., Senturk C., Sungur O \& Kiris, H.M. (2010). The importance of SMEs in developing economies. 2nd Inter Symp on Sus Dev, 2010 June:183-92. 
[17] Khan, S., \& Karodia, A.M. (2013). The effectiveness of using social networking technology for marketing in South Africa. Singaporean Journal of Business, Economics and Management Studies,51(1117),1-8. https://doi.org/10.12816/0003857

[18] Kioko, K.M. (2010). Use of social media to create awareness: a case of Kenyan banks. MA dissertation, University of Nairobi. Nairobi. Kenya.

[19] Lekhanya, L. M. (2013). The use of social media and social networks as the promotional tool for rural small, medium and micro enterprises in KwaZulu-Natal. International journal of scientific and research publications, 3(7),1-7.

[20] Malhotra, N. (2010). Marketing research: an applied orientation. 6th ed. Upper Saddle River, NJ: Pearson.

[21] Moodliar S. (2016). SA's management consulting industry needs major shake-up [Online] year [accessed 2020, April 5]; Available: http://www.biznisaafrica.co.za/sas-managementconsulting-industry-needs-major-shake-up/

[22] Muzaffar, F., \& Kamran, S. (2011). SMS advertising: youth attitude towards perceived informativeness, irritation and credibility. Interdisciplinary Journal of Contemporary Research in Business, 3(1), 230-245.

[23] Owino, J. O., Cherotich, M., Karuri, W. P., Gitonga, V., Kimuya, L., \& Kaumbulu, K. (2016). The influence of social media on brand equity in Kenyan banking industry. Pyrex Journal of Business and Finance Management Research, 2(1), 001-005.

[24] Rukuni, T. F., Shaw, G., Chetty, Y., Kgama, P., Kekana, P., \& Rogers, K. (2017). Viral marketing strategies and customer buying behavioural intentions at retail store in Johannesburg. Business Management and Strategy, 8(1), 59-83. https://doi.org/10.5296/bms.v8 i1.10676

[25] Saadeghvaziri, F., \& Hosseini, H. K. (2011). Mobile advertising: An investigation of factors creating positive attitude in Iranian customers. African journal of business management, 5(2), 394-404.

[26] Saunders, M., Lewis, P., \& Thornhill, A. (2009). Research methods for business students. Pearson education.

[27] Shashikala, R., \& Mahapatro, P. (2015). A study on analysing the effectiveness of social media in the era of mobile messenger apps with special reference to WhatsApp. International Journal of Research in Management, Social Sciences \& Technology, 10(10), 2320793.

[28] Siddique, S., \& Rashidi, M. Z. (2015). Influence of social media on brand consciousness: A study of apparel in Karachi. Global Journal of Management and Business Research, 15(6), 9-24.

[29] Snyman, L., \& Visser, J. H. (2014). The adoption of social media and social media marketing by dentists in South Africa. South African Dental Journal, 69(6), 258-264.

[30] Stangor, C. (2011). Research methods for the behavioural sciences. 4th ed. Place: Wadsworth.

[31] Stojanovic, I., Andreu, L., \& Curras-Perez, R. (2018). Effects of the intensity of use of social media on brand equity. European journal of management and business economics, 27(1), 83-100. https://doi.org/10.1108/ejmbe-11-2017-0049

[32] Van Puijenbroek, T., Poell, R. F., Kroon, B., \& Timmerman, V. (2014). The effect of social media use on work-related learning. Journal of Computer Assisted Learning, 30(2), 159-172. https://doi.org/10.1111/jcal.12037

[33] De Vries, N. J., \& Carlson, J. (2014). Examining the drivers and brand performance implications of customer engagement with brands in the social media environment. Journal of Brand Management, 21(6), 495-515. https://doi.org/10.1057/bm.2014.18 
[34] Vukasovič, T. (2013). Building successful brand by using social networking media. Journal of Media and Communication Studies, 5(6), 56-63.

[35] Yasin, N., \& Zahari, A. (2011). Does family and viral marketing have any effect on brand equity? Contemporary Marketing Review, 1(8), 1-13.

[36] Zernigah, K. I., \& Sohail, K. (2012). Consumers' attitude towards viral marketing in Pakistan. Management \& Marketing, 7(4), 645-662.

[37] Papadakis, S., Zaranis, N., \& Kalogiannakis, M. (2019). Parental involvement and attitudes towards young Greek children's mobile usage. International Journal of Child-Computer Interaction, 22, 100144. https://doi.org/10.1016/j.ijcci.2019.100144

[38] Pamacheche, R., Chinomona, R., \& Chuchu, T. (2016). Management's Commitment, Education and Ethics on Organisational Entrepreneurship: The Case of South African NonProfit Organisations. Journal of Economics and Behavioral Studies, 8(4), 133-143. https:// doi.org/10.22610/jebs.v8i4(j).1369

[39] Zollo, L., Filieri, R., Rialti, R., \& Yoon, S. (2020). Unpacking the relationship between social media marketing and brand equity: The mediating role of consumers' benefits and experience. Journal of Business Research, 117, 256-267. https://doi.org/10.1016/j.jbusres.20 $\underline{20.05 .001}$

[40] Bilgili, B., \& Ozkul, E. (2015). Brand Awareness, Brand Personality, Brand Loyalty and Consumer Satisfaction Relations in Brand Positioning Strategies (A Torku Brand Sample). Journal of Global Strategic Management, 9(2),89-106. https://doi.org/10.20460/jgsm.2015 $\underline{915576}$

[41] Ekhveh, A \& Darvishi, A.Z. (2015). The Impact of Brand Awareness on Re-purchase Intention of Customers with Trilogy of Emotions Approach (Case Study for Cell Phones). Applied mathematics in Engineering, Management and Technology, 3(4), 25-30.

[42] Jamil, B., \& Wong, C. H. (2010). Factors influencing repurchase intention of smartphones. Journal of Marketing Research, 4(12), 289-294.

[43] Malik, M. E., Ghafoor, M. M., Hafiz, K. I., Riaz, U., Hassan, N. U., Mustafa, M., \& Shahbaz, S. (2013). Importance of brand awareness and brand loyalty in assessing purchase intentions of consumer. International Journal of Business and Social Science, 4(5), pp. $167-171$.

[44] Dlodlo, N. \& Mafini, C., (2013). 'The relationship between technology acceptance and frequency of mobile commerce use amongst Generation Y consumers', Acta Commercii, 13(1), 1-8. https://doi.org/10.4102/ac.v13i1.176

[45] Arli, D. (2017). Does social media matter? Investigating the effect of social media features on consumer attitudes. Journal of Promotion Management, 23(4), 521-539. https://doi.org/ $\underline{10.1080 / 10496491.2017 .1297974}$

[46] Tsimonis, G., \& Dimitriadis, S. (2014). Brand strategies in social media. Marketing Intelligence \& Planning. 32(3), 328-344. https://doi.org/10.1108/mip-04-2013-0056

[47] Dehghani, M., Niaki, M. K., Ramezani, I., \& Sali, R. (2016). Evaluating the influence of YouTube advertising for attraction of young customers. Computers in human behavior, 59, 165-172. https://doi.org/10.1016/j.chb.2016.01.037

[48] Stephen, A. T., \& Toubia, O. (2010). Deriving value from social commerce networks. Journal of marketing research, 47(2), 215-228. https://doi.org/10.1509/jmkr.47.2.215

[49] Papadakis, S., Kalogiannakis, M., Sifaki, E., \& Vidakis, N. (2017). Access moodle using smart mobile phones. A case study in a Greek University. In Interactivity, Game Creation, Design, Learning, and Innovation (pp. 376-385). Springer, Cham. https://doi.org/10.1007/9 78-3-319-76908-0_36

[50] Kalogiannakis, M., \& Papadakis, S. (2007). The dual form of further education of educators in ICT: technological and pedagogical training. In C. Constantinou, Z. Zacharias \& M. 
Papaevripidou (Eds.) Proceedings of the 8th International Conference on Computer Based Learning in Science, Heraklion (Vol. 30, pp. 265-276).

[51] Kalogiannakis, M., Vassilakis, K., Alafodimos, C., Papadakis, S., Papachristos, D., \& Zafeiri, E. (2009). Adult Education and Lifelong Learning. The case of GSAE (General Secretary for Adult Education) in Greece. International Journal of Advanced Corporate Learning (iJAC), 2(4), 15-20. https://doi.org/10.3991/ijac.v2i4.981

[52] Kalogiannakis, M., \& Papadakis, S. (2008). Hybrid learning for women and socially sensitive groups for the promotion of digital literacy. 5th WSEAS / IASME International Conference on Engineering Education (EE'08), Heraklion, Greece, July 22-24, 2008.

\section{Authors}

Dr. Tarisai Fritz Rukuni is a Lecturer in the Department of Business Management at the University of the Free State in Bloemfontein, South Africa. He supervises $\mathrm{PhD}$, Masters and Honours research in the field of marketing and consumer behaviour. He also teaches services marketing at Honours level. He earned a PhD in Management from the University of the Western Cape, Cape Town, South Africa. Email: rukunitf@ufs.ac.za.

Dr. Eugine Tafadzwa Maziriri is currently a Senior Lecturer in the Department of Business Management at University of the Free State in Bloemfontein, South Africa. He teaches marketing courses to under-graduate and post-graduate students. He has a keen interest in consumer behaviour, green marketing and the development of small businesses. In addition, he has published numerous papers in peer-reviewed, international and local accredited journals. He has presented papers at local and international conferences. He earned his PhD in Business Sciences (Marketing) from the University of the Witwatersrand, Johannesburg, South Africa. Email: maziririet@ufs.ac.za.

Mr. Tsepo Mofoka is a Lecturer at the Ekurhuleni East TVET College in Johannesburg, South Africa. He is an emerging researcher as well as an MBA graduate from the Tshwane University of Technology in Pretoria, South Africa. Email: tshepom@eec.edu.za.

Article submitted 2020-04-14. Resubmitted 2020-07-20. Final acceptance 2020-07-20. Final version published as submitted by the authors. 